\title{
Investigation of the relationship between patellofemoral $(q)$ angle differences with lower extremity performance in young and veteran volleyball players
}

\author{
Kursat $\mathrm{HAZAR}^{1}$
}

${ }^{1}$ Mugla University, Rectorship, Physical Education and Sports Department, Mugla, Turkey.

Address Correspondence to K. Hazar e-mail: e-mail: kursathazar@hotmail.com

\begin{abstract}
This study was carried out to determine the relation between patella femoral (Q) angle differences and static equilibrium, flexibility and take-off force in young and veteran volleyball players. To the study 20 young males with an average age of $18 \pm$ 00,19 young females with a mean age of $18 \pm 73,21$ veteran males with a mean age of $49 \pm 04,20$ veteran females with a mean age of $48 \pm 70$ who are registered players in Muğla Provincial Directorate of Youth and Sports, a total of 80 athletes voluntarily participated. The height, body weight, right and left leg $\mathrm{Q}$ angles in standing and laying, balance, flexibility and vertical takeoff measurements were performed in the research group respectively. The statistical evaluation of the obtained data was done in SPSS 21.00 package program on a personal computer. In the data with normal distribution, the parametric statistical methods were used. While the analysis of variance (ANOVA) test was used for intergroup comparisons, the Turkey test was used for multiple comparisons, and the correlation level was used to determine the relationship between the variables and the significance level was taken as $\mathrm{p}<0.05$. According to the findings, there were significant differences between the $Q$ angles, balance, flexibility, and take-off values of the participants $(\mathrm{p}<0.01)$. Also, there was a positive relationship between $\mathrm{Q}$ angle values and elasticity values in standing and laying position, and a negative relationship between balance and take-off force values $(\mathrm{p}<0.05)$. As a result: $\mathrm{Q}$ angle values of volleyball players were examined and it was seen that the difference between groups has resulted from gender; the difference between young and veteran volleyball players was not statistically significant. As the $\mathrm{Q}$ angle increased, the increase in the elasticity values and the decrease in the balance and splash values were determined. In this respect, $Q$ angle differences are thought to be related to lower extremity performances of young and veteran volleyball players.
\end{abstract}

Key words: Volleyball, Q Angle, Lower Extremity Performance.

\section{INTRODUCTION}

Studies on moving athletic performance forward and what factors are effective in sports to whet the appetite of the scientists on the basis of the studies conducted in the direction of developments in the sports sciences. Considering the differences between sports branches, it has become a focus of interest to know whether the postural properties of the branch affect the bio-motor characteristics.

When looked at volleyball players; besides lower extremity's being powerful as a basis, lower extremity which is a primary factor in the continuity of the sports and effective on aerobic performance has to be at a specific level (11). Especially in today's volleyball, although it is known that players' having high technical characteristics is not an absolute structure on success; the difference that you can create between two teams which have the same players who have equal technique levels passes from the force feature (1). As in all team sports, in the struggle to have the ball in volleyball in the quick force and force continuity comes into the prominence (9). The physical and physiological 
structure required by this sports branch has an important role in achieving success (10). At the same time, success depends on good technique as well as a good application of basic motor properties (7).

While volleyball is defined as power volleyball in today's world; if you add enough force to the technical characteristics of the athlete, the probability of success will increase (20). In addition, volleyball is not a time-dependent, high-paced, quickness, force, mobility, flexibility, durability, and leap-based dynamic game (12). In the conducted studies, it was found that being successful in volleyball was directly related to basic motor characteristics such as vertical take-off, speed, flexibility (8). Volleyball requires some special physical requirements such as finger force for the pass, high take-off for block movement, flexibility, and speed for dunking (11).

Performance in volleyball players is effective motoric features as well as postural properties affecting these characteristics. In this respect, it is necessary to determine which physical or physiological characteristics affect each other in order to increase performance. Besides Patellafemoral angle is commonly used in the kinesiological evaluation of the knee joint and lower extremity, it is defined as Q angle in today's world. The angle $Q$ is the angle of the m.quadriceps femoris muscle and is defined as the narrow-angle at the intersection of the midline of the patella with the Spina iliaca anterior superior and the middle of the patella and the tuberositas tibiae laterally (2). When this angle is embraced mechanically, it is understood that patella is effective on femoral translation (16). When angle $Q$ is above 15-20 degrees, it is considered that the knee joint causes deterioration of the extension mechanism and patella causes femoral pain with increasing tendency to slide laterally (3). It has been emphasized that it causes various pain and disability in abnormally low values (19).

However, it is possible to incorporate the postural characteristics of the individual into the structural feature when it is mentioned about the necessity of structural and personality factors (15). as a prerequisite for obtaining efficiency in sports. In this study, it is important to know whether these differences have any relation with lower extremity performance by examining $Q$ angle differences between young and veteran volleyball players. In this respect, the study was carried out to determine whether the angles of $\mathrm{Q}$ are related to static equilibrium, flexibility and take-off force performances.

\section{MATERIAAL AND METHOD}

Participants: To the study 20 young males with an average age of $18 \pm 00,19$ young females with a mean age of $18 \pm 73,21$ veteran males with a mean age of $49 \pm 04,20$ veteran females with a mean age of $48 \pm 70$ who are registered players in Muğla Provincial Directorate of Youth and Sports, a total of 80 athletes voluntarily participated. The participants were given detailed information before the measurements and signed a document indicating that they were volunteers. In addition, participants with health problems and knee injuries, and both medial condyle and medial molleol intervals of $2,5 \mathrm{~cm}$ and above were excluded from the scope of the study by accepting genu varus and genu valgus (knee deformity).

\section{Data Collection Methods:}

The height, body weight, right and left leg $\mathrm{Q}$ angles in standing and laying, balance, flexibility, and vertical take-off measurements were performed in the research group respectively.

\section{Height and Body Weight Measurements:}

The height values of the groups included in the study were measured with a stadiometer with a sensitivity of $0.01 \mathrm{~m}$ and body weight values were measured with a precision scale of $0.1 \mathrm{~kg}$ (SECA, Germany).

\section{Q Angle Measurements:}

In the measurements made in standing position, the quadriceps femoris muscle was loosened by asking the participants to press the bare feet to the ground, while the knee joint was an extension and the hip was measured while the hip was loose flexion. Measurements were made with $60 \mathrm{~cm}$ long arm, $25 \mathrm{~cm}$-short armed goniometer. The measurements were carefully marked with the center of the patella and the midpoint of the tuberositas tibia from the spinal iliac anterior valve (SIAS). The center of the long arm to the midpoint of the gynameter was placed in the middle of the long arm and the short arm was taken to the middle of the tuberositas tibia. In addition to their 
angles, varus and valgus deformities were determined. Both medial molleoles and medial condyle ranges were measured with a modified caliper. In the measurements, the distance between the medial femoral condyles and those with a diameter of $2.5 \mathrm{~cm}$ and above was determined as valgus deformity.

\section{Static Balance measurements:}

The static balances of the study group were determined by flamingo balance test (FBT). The participant tries to maintain his balance with his dominant foot on a wooden balance beam $50 \mathrm{~cm}$ long, $4 \mathrm{~cm}$ high and $3 \mathrm{~cm}$ wide. He pulls his other foot from his knees bent to the buttocks and holds it with his hand on the same side. While the one foot is on the balance beam, the time is started and he tries to maintain his balance for 1 minute. In cases where the balance is broken (if he leaves his feet, falls from the wooden floor, touches the ground with any part of his body) the time is stopped. The participant enters the balance instrument again and re-starts the balance from where it left off. When the 1-minute period is completed, the participant's attempt to maintain a balance is recorded as a piece (17).

\section{Flexibility Measurements:}

The flexibility measurements of the participants in the research group were done with $32 \mathrm{~cm}$. height and $35 \mathrm{~cm}$. length box, top of which was divided into $\mathrm{cm}$ using sit and reach test method. The participants sat with a barefoot in front of the sit and FINDINGS reach box and stretch their legs and put their soles on the stand. The participant then extended his trunk without bending his knees as far as possible in the dimensioned section on the stand. The most extreme point that fingers can reach was measured in $\mathrm{cm}$ and the maximum value that was achieved after the measurements were taken was recorded.

\section{Vertical Take-off Measurements:}

Participants extend their hands upwards on a flat wall, the point where the fingertip touched is marked. Then they step on the wall from where they are without stepping up to the wall touches. The obtained value by measuring the distance that the athlete took-off was recorded in $\mathrm{cm}$. This test was repeated three times and the highest value was determined as the jump distance of the athlete (18).

\section{Data analysis:}

Statistical analysis of the obtained data was done in SPSS 21.00 package program on a personal computer. The normality test was performed with the Kolmagorow-simirnov test and the data were found to be in normal distribution. In the comparisons between groups, while analysis of variance (ANOVA) test was used, multiple comparisons were made by Tukey test and correlation analysis was used to determine the relationship between the variables. The significance level was taken as $p$ $<0.05$ in parametric tests.

\begin{tabular}{|c|c|c|c|c|c|}
\hline Variables & & Minimum & Maximum & Mean & Std. D. \\
\hline \multirow{4}{*}{ Young Males N=20 } & Age & 17.00 & 19.00 & 18.00 & .794 \\
\hline & Height & 176.00 & 192.00 & 183.00 & 5.619 \\
\hline & Weight & 58.00 & 86.50 & 72.68 & 9.979 \\
\hline & Sports Year & 3.00 & 11.00 & 7.60 & 3.315 \\
\hline \multirow{4}{*}{ Young FemalesN=19 } & Age & 16.00 & 21.00 & 18.73 & 1.557 \\
\hline & Height & 164.00 & 178.00 & 171.57 & 4.610 \\
\hline & Weight & 56.00 & 85.00 & 65.84 & 6.825 \\
\hline & Sports Year & 4.00 & 13.00 & 8.89 & 2.998 \\
\hline \multirow{4}{*}{ Veteran Males N=21 } & Age & 41.00 & 58.00 & 49.04 & 7.116 \\
\hline & Height & 169.00 & 190.00 & 182.00 & 6.188 \\
\hline & Weight & 73.00 & 96.00 & 82.19 & 6.749 \\
\hline & Sports Year & 15.00 & 46.00 & 27.19 & 9.325 \\
\hline \multirow{4}{*}{ Veteran Females $N=20$} & Age & 40.00 & 63.00 & 48.70 & 7.623 \\
\hline & Height & 155.00 & 175.00 & 162.80 & 6.287 \\
\hline & Weight & 51.00 & 78.50 & 62.25 & 7.901 \\
\hline & Sports Year & 5.00 & 45.00 & 18.8000 & 13.563 \\
\hline
\end{tabular}


Table.2. Comparison Analysis on Q Angle Values of the Groups in the Research

\begin{tabular}{|c|c|c|c|c|c|c|}
\hline Variables & & $\mathrm{N}$ & \pm & Std. D. & $\mathrm{F}$ & $\mathrm{P}$ \\
\hline \multirow{4}{*}{$\begin{array}{c}\text { Standing Right Leg } \\
\text { Q Angle }\end{array}$} & Young Male & 20 & 9.75 & .850 & \multirow{4}{*}{73.640} & \multirow{4}{*}{$.000^{* *}$} \\
\hline & Young Female & 19 & 16.68 & 3.037 & & \\
\hline & VeteranMale & 21 & 10.80 & 1.030 & & \\
\hline & Veteran Female & 20 & 18.05 & 2.855 & & \\
\hline \multirow{4}{*}{$\begin{array}{c}\text { Standing Left Leg Q } \\
\text { Angle }\end{array}$} & Young Male & 20 & 10.90 & 1.483 & \multirow{5}{*}{77.785} & \multirow{5}{*}{$.000^{* *}$} \\
\hline & Young Female & 19 & 19.42 & 2.610 & & \\
\hline & Veteran Male & 21 & 9.71 & 2.390 & & \\
\hline & Veteran Female & 20 & 16.90 & 2.770 & & \\
\hline \multirow{4}{*}{$\begin{array}{c}\text { Laying Right Leg Q } \\
\text { Angle }\end{array}$} & Young Male & 20 & 11.00 & 1.654 & & \\
\hline & Young Female & 19 & 20.42 & 2.387 & \multirow{3}{*}{78.148} & \multirow{3}{*}{$.000^{* *}$} \\
\hline & Veteran Male & 21 & 9.52 & 2.337 & & \\
\hline & Veteran Female & 20 & 17.00 & 3.554 & & \\
\hline \multirow{4}{*}{$\begin{array}{c}\text { Laying Left Left Q } \\
\text { Angle }\end{array}$} & Young Male & 20 & 10.20 & 1.641 & \multirow{4}{*}{69.441} & \multirow{4}{*}{$.000^{* *}$} \\
\hline & Young Female & 19 & 17.05 & 1.508 & & \\
\hline & Veteran Male & 21 & 8.52 & 1.913 & & \\
\hline & Veteran Female & 20 & 16.75 & 3.711 & & \\
\hline
\end{tabular}

When we look at Table 2 , it is seen that there is a significant difference $(\mathrm{p}<0.01)$ between the standing right leg, standing left leg and laying right leg and laying left leg $\mathrm{Q}$ angle values.

\begin{tabular}{|c|c|c|c|c|c|}
\hline \multicolumn{6}{|c|}{ Table.3.Multiple Comparisons of Q Values of the Groups in the Research } \\
\hline Variables & (I)Category & (J) Category & Mean Difference & Std. D. & P. \\
\hline \multirow{12}{*}{$\begin{array}{c}\text { Standing Right Leg } \\
\text { Q Angle }\end{array}$} & \multirow[t]{3}{*}{ Young Male } & Young Female & $-6.93421^{*}$ & .69340 & .000 \\
\hline & & Veteran Male & -1.05952 & .67626 & .404 \\
\hline & & Veteran Female & $-8.30000^{*}$ & .68445 & .000 \\
\hline & \multirow[t]{3}{*}{ Young Female } & Young Male & $6.93421^{*}$ & .69340 & .000 \\
\hline & & Veteran Male & $5.87469^{*}$ & .68531 & .000 \\
\hline & & Veteran Female & -1.36579 & .69340 & .209 \\
\hline & \multirow[t]{3}{*}{ Veteran Male } & Young Male & 1.05952 & .67626 & .404 \\
\hline & & Young Female & $-5.87469^{*}$ & .68531 & .000 \\
\hline & & Veteran Female & $-7.24048^{*}$ & .67626 & .000 \\
\hline & \multirow[t]{3}{*}{ Veteran Female } & Young Male & $8.30000^{*}$ & .68445 & .000 \\
\hline & & Young Female & 1.36579 & .69340 & .209 \\
\hline & & Veteran Male & $7.24048^{*}$ & .67626 & .000 \\
\hline \multirow{12}{*}{$\begin{array}{l}\text { Standing } \\
\text { Left Leg } \\
\text { Q Angle }\end{array}$} & \multirow[t]{3}{*}{ Young Male } & Young Female & $-8.52105^{*}$ & .75715 & .000 \\
\hline & & Veteran Male & 1.18571 & .73843 & .382 \\
\hline & & Veteran Female & $-6.00000^{*}$ & .74738 & .000 \\
\hline & \multirow{3}{*}{ Young Female } & Young Male & $8.52105^{*}$ & .75715 & .000 \\
\hline & & Veteran Male & $9.70677^{*}$ & .74831 & .000 \\
\hline & & Veteran Female & $2.52105^{*}$ & .75715 & .007 \\
\hline & \multirow{3}{*}{ VeteranMale } & Young Male & -1.18571 & .73843 & .382 \\
\hline & & Young Female & $-9.70677^{*}$ & .74831 & .000 \\
\hline & & Veteran Female & $-7.18571^{*}$ & .73843 & .000 \\
\hline & \multirow[t]{3}{*}{ Veteran Female } & Young Male & $6.00000^{*}$ & .74738 & .000 \\
\hline & & Young Female & $-2.52105^{*}$ & .75715 & .007 \\
\hline & & VeteranMale & $7.18571^{*}$ & .73843 & .000 \\
\hline \multirow{7}{*}{$\begin{array}{l}\text { Laying } \\
\text { Right Leg }\end{array}$} & \multirow[t]{3}{*}{ Young Male } & Young Female & $-9.42105^{*}$ & .82488 & ,000 \\
\hline & & VeteranMale & 1.47619 & .80449 & .265 \\
\hline & & Veteran Female & $-6.00000^{*}$ & .81424 & .000 \\
\hline & \multirow[t]{3}{*}{ Young Female } & Young Male & $9.42105^{*}$ & .82488 & .000 \\
\hline & & Veteran Male & $10.89724^{*}$ & .81526 & .000 \\
\hline & & Veteran Female & $3.42105^{*}$ & .82488 & .000 \\
\hline & Veteran Male & Young Male & -1.47619 & .80449 & .265 \\
\hline
\end{tabular}




\begin{tabular}{|c|c|c|c|c|c|}
\hline \multirow[t]{5}{*}{ Q Angle } & & Young Female & $-10.89724^{*}$ & .81526 & .000 \\
\hline & & Veteran Female & $-7.47619^{*}$ & .80449 & .000 \\
\hline & \multirow[t]{3}{*}{ Veteran Female } & Young Male & $6.00000^{*}$ & .81424 & .000 \\
\hline & & Young Female & $-3.42105^{*}$ & .82488 & .000 \\
\hline & & Veteran Male & $7.47619^{*}$ & .80449 & .000 \\
\hline \multirow{12}{*}{$\begin{array}{c}\text { Laying } \\
\text { Left Leg } \\
\text { Q Angle }\end{array}$} & \multirow[t]{3}{*}{ Young Male } & Young Female & $-6.85263^{*}$ & .75948 & .000 \\
\hline & & Veteran Male & 1.67619 & .74070 & .116 \\
\hline & & VeteranFemale & $-6.55000^{*}$ & .74968 & .000 \\
\hline & \multirow[t]{3}{*}{ Young Female } & Young Male & $6.85263^{*}$ & .75948 & .000 \\
\hline & & Veteran Male & $8.52882^{*}$ & .75062 & .000 \\
\hline & & Veteran Female & .30263 & .75948 & .978 \\
\hline & \multirow[t]{3}{*}{ Veteran Male } & Young Male & -1.67619 & .74070 & .116 \\
\hline & & Young Female & $-8.52882^{*}$ & .75062 & .000 \\
\hline & & Veteran Female & $-8.22619^{*}$ & .74070 & .000 \\
\hline & \multirow[t]{3}{*}{ Veteran Female } & Young Male & $6.55000^{*}$ & .74968 & .000 \\
\hline & & Young Female & -.30263 & .75948 & .978 \\
\hline & & Veteran Male & $8.22619^{*}$ & .74070 & .000 \\
\hline
\end{tabular}

${ }^{*}: p<0,05, \quad{ }^{* *}: p<0,01$

When the right leg $\mathrm{Q}$ angle values are examined; there were significant differences between the average values of young and veteran males and young and veteran females

$(p<0.01)$. The values of young and veteran men are lower than those of young and veteran women, respectively.

There was a significant difference between young men and young and veteran women in standing left leg $Q$ angle values $(p<0.01)$. There was a significant difference between the values of young females and young veteran men and veteran women; veteran males and young and veteran females; veteran women and young males, young women and veteran males $(p<0.01)$.

While there were significant differences between the genders in the laying right leg $Q$ angle values $(p$
$<0.01$ ), the values of young and veteran males were lower than the females'.

In addition, there was a significant difference between the values of young females and veteran females in the right leg $Q$ angle values $(p<0.01)$. It is seen that the values of veteran females are lower than the values of young females.

There was a significant difference between the average values of young and veteran males and young and veteran females in the left leg $Q$ angle values $(p<0.01)$. The values of veteran males were found to be lower than that of young males and the values of veteran females were lower than the values of young females.

Table.4. Comparison on Lower-Extremity Performances of the Groups in the Research

\begin{tabular}{|c|c|c|c|c|c|c|}
\hline Variables & & $\mathrm{N}$ & Mean & Std. D. & $\mathrm{F}$ & $\mathrm{P}$ \\
\hline \multirow{4}{*}{ Balance } & Young Male & 20 & 3,4500 & 1,14593 & \multirow{4}{*}{13,209} & \multirow{4}{*}{, $000^{* *}$} \\
\hline & Young Female & 19 & 5,0526 & 1,07877 & & \\
\hline & Veteran Male & 21 & 4,1905 & 1,03049 & & \\
\hline & Veteran Female & 20 & 5,7000 & 1,52523 & & \\
\hline \multirow{4}{*}{ Flexibility } & Young Male & 20 & 30,0000 & 5,50598 & \multirow{4}{*}{25,918} & \multirow{4}{*}{, $000^{* *}$} \\
\hline & Young Female & 19 & 35,2105 & 3,70554 & & \\
\hline & Veteran Male & 21 & 20,1905 & 7,27749 & & \\
\hline & Veteran Female & 20 & 29,8000 & 4,85148 & & \\
\hline \multirow{4}{*}{ Take-Off Force } & Young Male & 20 & 56,3000 & 6,79086 & \multirow{4}{*}{90,033} & \multirow{4}{*}{, $000^{* *}$} \\
\hline & Young Female & 19 & 37,4211 & 6,23000 & & \\
\hline & VeteranMale & 21 & 28,6190 & 7,13075 & & \\
\hline & Veteran Female & 20 & 27,2000 & 4,91614 & & \\
\hline
\end{tabular}

${ }^{* *}: \mathrm{p}<0,01$

When Table 4 is examined, it was found that

there was a significant difference between the 
balance, flexibility and take-off force performance values of the groups in the study $(\mathrm{p}<0.01)$.

Table.5. Multiple Comparisons on Lower-Extremity Performances of the Groups in the Research

\begin{tabular}{|c|c|c|c|c|c|}
\hline Variables & (I) Category & (J) Category & Mean Difference & Std. D. & $\mathrm{P}$ \\
\hline \multirow{12}{*}{ Balance } & \multirow[t]{3}{*}{ Young Male } & Young female & $-1.60263^{*}$ & .38775 & .001 \\
\hline & & Veteranmale & -.74048 & .37816 & .213 \\
\hline & & Veteranfemale & $-2.25000^{*}$ & .38275 & .000 \\
\hline & \multirow[t]{3}{*}{ Young Female } & Young male & $1.60263^{*}$ & .38775 & .001 \\
\hline & & Veteranmale & .86216 & .38322 & .119 \\
\hline & & Veteranfemale & -.64737 & .38775 & .347 \\
\hline & \multirow[t]{3}{*}{ Veteran Male } & Young male & .74048 & .37816 & .213 \\
\hline & & Young female & -.86216 & .38322 & .119 \\
\hline & & Veteranfemale & $-1.50952^{*}$ & .37816 & .001 \\
\hline & \multirow[t]{3}{*}{ Veteranfemale } & Young male & $2.25000^{*}$ & .38275 & .000 \\
\hline & & Young female & .64737 & .38775 & .347 \\
\hline & & Veteranmale & $1.50952^{*}$ & .37816 & .001 \\
\hline \multirow{12}{*}{ Flexibility } & \multirow[t]{3}{*}{ Young Male } & Young female & $-5.21053^{*}$ & 1.77367 & .022 \\
\hline & & Veteran male & $9.80952^{*}$ & 1.72982 & .000 \\
\hline & & Veteran female & .20000 & 1.75079 & .999 \\
\hline & \multirow[t]{3}{*}{ Young Female } & Young male & $5.21053^{*}$ & 1.77367 & .022 \\
\hline & & Veteran male & $15.02005^{*}$ & 1.75298 & .000 \\
\hline & & Veteran female & $5.41053^{*}$ & 1.77367 & .016 \\
\hline & \multirow[t]{3}{*}{ Veteran Male } & Young male & $-9.80952^{*}$ & 1.72982 & .000 \\
\hline & & Young female & $-15.02005^{*}$ & 1.75298 & .000 \\
\hline & & Veteran female & $-9.60952^{*}$ & 1.72982 & .000 \\
\hline & \multirow[t]{3}{*}{ Veteran Female } & Young male & -.20000 & 1.75079 & .999 \\
\hline & & Young female & $-5.41053^{*}$ & 1.77367 & .016 \\
\hline & & Veteran male & $9.60952^{*}$ & 1.72982 & .000 \\
\hline \multirow{12}{*}{$\begin{array}{l}\text { Take-Off } \\
\text { Force }\end{array}$} & \multirow[t]{3}{*}{ Young Male } & Young female & $18.87895^{*}$ & 2.02980 & .000 \\
\hline & & Master male & $27.68095^{*}$ & 1.97961 & .000 \\
\hline & & Master female & $29.10000^{*}$ & 2.00361 & .000 \\
\hline & \multirow[t]{3}{*}{ Young Female } & Young male & $-18.87895^{*}$ & 2.02980 & .000 \\
\hline & & Veteran male & $8.80201^{*}$ & 2.00612 & .000 \\
\hline & & Veteran female & $10.22105^{*}$ & 2.02980 & .000 \\
\hline & \multirow[t]{3}{*}{ Veteran Male } & Young male & $-27.68095^{*}$ & 1.97961 & .000 \\
\hline & & Young female & $-8.80201^{*}$ & 2.00612 & .000 \\
\hline & & Veteran female & 1.41905 & 1.97961 & .890 \\
\hline & \multirow[t]{3}{*}{ Veteran Female } & Young male & $-29.10000^{*}$ & 2.00361 & .000 \\
\hline & & Young female & $-10.22105^{*}$ & 2.02980 & .000 \\
\hline & & Veteran male & -1.41905 & 1.97961 & .890 \\
\hline
\end{tabular}

As seen in Table 5, there was a significant difference between the values of young males and young and veteran females in the balance values of the groups in the study $(p<0.01)$.Young males' balances are better than young and veteran females.However, there was a significant difference between veteran males and veteran females $(p<0.01)$. The balance of veteran males is better than veteran females.

females and veteran females $(p<0.01)$. The values of young females are higher than veteran female.
When the flexibility values were examined, there was a significant difference between the average values of young males and young females and veteran males $(p<0.01)$. The values of young females are higher than those of young and veteran males, while the values of young males are higher than veteran males. There was also a significant difference between the values of young 
Table.6. Q Angle Variables' Relationship with Other Variables Related to the Groups

\begin{tabular}{|c|c|c|c|c|c|c|c|}
\hline Variables & $\begin{array}{l}\text { Standing } \\
\text { Right Leg }\end{array}$ & $\begin{array}{l}\text { Standing Left } \\
\text { Leg }\end{array}$ & $\begin{array}{l}\text { Laying } \\
\text { Right Leg }\end{array}$ & $\begin{array}{l}\text { Laying } \\
\text { Left Leg }\end{array}$ & Balance & Flexibility & $\begin{array}{l}\text { Take-Off } \\
\text { Force }\end{array}$ \\
\hline \multirow[b]{2}{*}{$\begin{array}{l}\text { StandingRight } \\
\text { Leg Q Angle }\end{array}$} & 1 & $.766^{* *}$ & $.778^{* *}$ & $.789^{* *}$ & $-.367^{* *}$ & $.337^{* *}$ & $-.433^{* *}$ \\
\hline & & .000 & .000 & .000 & .001 & .002 & .000 \\
\hline \multirow{3}{*}{$\begin{array}{l}\text { Standing Left } \\
\text { Leg Q Angle }\end{array}$} & $.766^{* *}$ & 1 & $.832^{* *}$ & $.839^{* *}$ & -.125 & $.460^{* *}$ & -.158 \\
\hline & .000 & & .000 & .000 & .268 & .000 & .160 \\
\hline & $.778^{* *}$ & $.832^{* *}$ & 1 & $.861^{* *}$ & $-.226^{*}$ & $.507^{* *}$ & -.156 \\
\hline $\begin{array}{l}\text { Laying Right } \\
\text { Leg Q Angle }\end{array}$ & .000 & .000 & & .000 & .044 & .000 & .168 \\
\hline \multirow{2}{*}{$\begin{array}{l}\text { Laying Left } \\
\text { Leg Q Angle }\end{array}$} & $.789^{* *}$ & $.839^{* *}$ & $.861^{* *}$ & 1 & -.215 & $.446^{* *}$ & -.179 \\
\hline & .000 & .000 & .000 & & .055 & .000 & .112 \\
\hline
\end{tabular}

Although Table 6 shows that there is a positive correlation between $Q$ angle values and flexibility values in standing and laying right leg position, there was a negative relationship between the $Q$ angles, the balance and take-off force values in the standing and laying position $(\mathrm{p}<0.05)$.

\section{DISCUSSION AND RESULT}

Determining whether there is a relationship between lower-extremity performance and these differences and with the aim of defining the relationship between static balance, flexibility and take-off force by examining the $Q$ angle differences of the young and veteran volleyball in the study; in the result of the comparison analysis about $Q$ angle values of the groups in the research, it is found that standing right leg $\mathrm{Q}$ angle average of the young males is 9,7500; young females 16,6842; veteran males 10,8095; veteran females 18,0500; standing left $\mathrm{Q}$ angle averages of the young males 10,9000; young females 19,4211; veteran 9,7143; veteran females 16,9000; laying right leg $Q$ angle of the young females 11,0000; young females 20,4211; veteran females 9,5238; veteran females 17,0000; laying left leg Q angle of the males 10,2000; young females 17,0526; veteran males 8,5238; veteran females 16,7500. It was found that there was a significant difference ( $\mathrm{p}<0.01$ ) between the standing right leg, standing left leg and laying right leg and laying left leg $Q$ angle values.

Significant differences were found between the Q-angle values of the young and veteran volleyball players in the standing and supine positions where the measurements were made, and these angles were found to be lower in

the young and veteran female volleyball players and lower in the young and veteran male volleyball Turk ل Sport Exe 2019; 21():136-143 (4) 2019 Faculty of Sport Sciences, Selcuk University players. Although there was no significance related to the changes in $\mathrm{Q}$ angles due to aging in the research hypothesis, the $Q$ angle values of veteran male and female volleyball players were lower in both positions compared to the values of young male and female volleyball players.

Although there is no definite value for $Q$ angle averages in the literature, it is reported that the general reference values are 8-14 (average 10 degrees) in males and 11-20 (average 15 degrees) in females. In males and 15 females, values greater than 20 degrees were evaluated as abnormal(13). In a study, Horton and hall (6).found that there is a correlation in terms of gender at the $Q$ angles. In another study, it was found that $Q$ angles were higher in females compared to males in the measurements of standing and laying position (4). In this study, values close to the reference values in the literature were obtained (14). Q angles of young and veteran female volleyball players compared to younger and veteran female volleyball players are found to have higher values, the research is considered to overlap with the literature.

In addition, it was found that there was a significant difference between the balance, flexibility and take-off force performance values of the groups ( $p<0.01)$. In the balance values of the groups in the study, the balance values of the young males were found to be higher than the young and veteran females, while the balance values of the veteran males were found to be significantly higher than the veteran females $(p<0.01)$. In the values of flexibility, the values of young females were found to be significantly higher than in males $(p<0,01)$. When the vertical take-off values were examined, the values of young males were found to be higher than young females and veteran males' values were 
found to be higher than the veteran females ( $p$ $<0.01)$.

There are studies suggesting that male athletes' balance values are higher than females and flexibility values of female athletes are higher than males (4). In addition, cuadriceps shows that the strength and the force emerging in the muscle is higher due to the increased muscle mass and hamstring muscle fibers (5). In line with this information, our study is consistent with the literature.

In addition, there was a positive correlation between $Q$ angle variables and flexibility values of the groups, while it was found that there was a negative correlation between $Q$ angle values in standing and laying position and balance and take-off force values $(\mathrm{p}<0.05)$.

As a result, $Q$ angle values of volleyball players are examined; the difference between groups was found to be gender-related, while the difference between young and veteran volleyball players was not statistically significant. As the $\mathrm{Q}$ angle increased, the increase in the flexibility values and the decrease in the balance and take-off values were found. In this respect, $Q$ angle differences are thought to be related to lower extremity performances of young and veteran volleyball players

\section{REFERENCES}

1. Bompa. T.O.. (1998). Antrenman kuramı ve Yöntemi. Çeviri; Keskin.. Tuner. A. Bağırgan Yayınevi: Ankara

2. Brody. D. M.. 1980 "Running injuries". Ciba Clinical Symposia 32 (4): 9-13.

3. Byl T. Cole J. Livingston L. 2000. What determines the magnitude of the Q-angle? A preliminary study of selected skeletal and muscular measures. Journal of Sports Rehabilitation. 2000;9.26-34.

4. Caylor D. Fites R. Worrell T. The relationship between quadriceps angle and anterior knee pain syndrome. JOSPT. 1993;17.11-5

5. Grant. S.. Hynes. V.. Whittaker. A.. \& Aitchison. T. (1996). Anthropometric. strength. endurance and flexibility characteristics of elite and recreational climbers. Journal of sports sciences. 14(4). 301-309.

6. Horton MG. Hall TL. Quadriceps femoris muscle anglenormal values and relationships with gender and selected skeletal measures. Phys. Ther. 1989;69.897-901

7. İpek. Z.. Ziyagil. M.A.. (2002). Erkek ve bayan voleybolcuların fiziksel özellikleri ve fizyolojik kapasitelerinin sedanterlerle karşılaştırılması. Beden Eğitimi ve Spor Bil. Dergi. 4(2). 12-16.

8. Koç H. Aslan CS. Erkek Hentbol ve Voleybol Sporcularının Seçilmiş Fiziksel ve Motorik Özelliklerinin Karşılaştırılması. Selçuk Üniversitesi Beden Eğitim ve Spor Bilim Dergisi. 2010; 12(3): 227-231.

9. Koç. H.. Özcan. K.. Pulur. A.. Ayaz. A.. (2007). Elit bayan hentbolcular ile voleybolcuların bazı fiziksel ve fizyolojik parametrelerinin karşılaştırılması. Spormetre Beden Eğitimi ve Spor Bilimleri Dergisi. 5(3). 123-128.

10. Lale. B.. Müniroğlu. S.. Çoruh. E.E.. Sunay. H.. (2003). Türk erkek voleybol milli takımının somatotip özelliklerinin incelenmesi. Spormetre Bed. Ĕ̆. Ve Spor Bilimleri Dergisi. 1(1). 53-56.

11. Nalçakan GR. Voleybolcuların İzokinetik Kas Kuvvetleri ile Dikey Sıçrama Yükseklikleri Arasındaki İlişki düzeyi. Spor Fizyolojisi Yüksek Lisans Tezi. Ege Üniversitesi Sağlık Bilimleri Enstitüsü. İzmir. 2001.

12. Puhl J. Case S. Fleck S. Handel V.Physicalandphysiologicalcharacteristics of elitevolleyballplayers. Res. Quart. 1982; 53: 257-262.

13. Recreational Climbers. Journal of Sports Sciences. 14: 301-309. 1996..

14. Riley. D. (1995). "Voleybol İçin Kuvvetlilik Çalışması". Çeviri: H. Can. Hacettepe Üniversitesi Voleybol Bilim ve Teknoloji Dergisi. 3 (5): 22-39.

15. Schnabel G. Harre D. Borde A. Grundkonzept "SportlicheLeistung". In: Trainingswissenschaft. 10. Ausg. G Schnabel. Hrsg. Berlin. SportVerlag. 1997. 32-79.

16. Schulties SS. Francis RS. Fisher AG. Van der Graaf KM. Does the $Q$ angle reflect the forces on the patella in thefrontal plane? Phys Ther 1995; 75(1): 24-30

17. Şipal MC. (1989). Eurofit Bedensel Yetenek Testleri El Kitabı. T.C. Başbakanlık G.S. G.M Dış İlişkiler Dairesi Başkanlığı Yayını. Yayın No 78. Ankara.

18. Tamer. K. (1995): Sporda Fiziksel ve Fizyolojik Performansın ölçülmesi ve Değerlendirilmesi. Türkerler Kitabevi. Ankara. 4-158.

19. Wilson T. Kitsell F. Is the Q-angle an absolute or variable measure? Physiotherapy. 2002;88.296-302

20. Yenigün. Ö. (2003). "Voleybolcuların alt ekstremite antropometrik ölçümleri ile biodex aleti ile ölçülen diz fleksiyon ekstansiyon kas kuvvetlerinin değerlendirilmesi". Kocaeli Üniversitesi Sağlık Bilimleri Enstitüsü Yüksek Lisans Tezi. Kocaeli 